\title{
The Effect of Pre-service Mathematics Teachers' Beliefs about Mathematics Teaching-Learning on Their Mathematics Teaching Anxiety ${ }^{1}$
}

\author{
Murat Peker \\ Prof., Afyon Kocatepe University, Afyonkarahisar, Turkey, peker@aku.edu.tr \\ Mustafa Ulu \\ Asst. Prof., Dumlupinar University, Kutahya, Turkey, mustafa.ulu@dpu.edu.tr
}

This study aims to investigate the presence and the level of the effect of preservice mathematics teachers' beliefs about mathematics teaching and learning on mathematics teaching anxiety. The predictive correlational survey model was utilized in this study. We used mathematics-related beliefs scale and mathematics teaching anxiety scale in the study to collect the data. The data were analysed using structural equation model. The results of the study demonstrated that traditional beliefs did not affect the sub-factors of the mathematics teaching-related anxiety scale. On the other hand, the results showed that constructivist beliefs directly negatively affect anxiety about self-confidence regarding mathematics teaching and anxiety about mathematics teaching attitude. Another finding was that constructivist beliefs directly affect anxiety about content knowledge regarding mathematics teaching and also negatively affect this anxiety through anxiety about self-confidence. Similarly, constructivist beliefs directly affect the anxiety about pedagogical content knowledge regarding mathematics teaching, while also affecting this anxiety negatively through anxiety about mathematics teaching attitude. When the variance rates of the final model were evaluated, constructivist beliefs, anxiety about self-confidence regarding mathematics teaching, anxiety about mathematics teaching attitude and anxiety about content knowledge can account for $63 \%$ of the variance in anxiety about pedagogical content knowledge.

Keywords: mathematics, teaching, learning, beliefs, anxiety

\section{INTRODUCTION}

Attitudes are psychological structures composed of cognitive, affective and behavioural components, and they also have an effect on all future thinking processes and behaviors

\footnotetext{
${ }^{1}$ This study is a part of the project of "16.KARIYER.81", supported by Afyon Kocatepe University, Scientific Research Projects Coordination Unit.

Citation: Peker, M., \& Ulu, M. (2018). The Effect of Pre-service Mathematics Teachers' Beliefs about Mathematics Teaching-Learning on Their Mathematics Teaching Anxiety. International Journal of Instruction, 11(3), 249-264. https://doi.org/10.12973/iji.2018.11318a
} 
of the individual in one way or another. In most cases, the attitude of an individual is based on the individual's positive or negative attitudes toward an object (Maio \& Haddock, 2015). Maio and Haddock (2015) reported that cognitive, affective and behavioral components affect attitudes (See Figure 1). Instructional designers also accept that three main components that form attitudes are cognitive, affective and behavioral components (Akinsola \& Olowojaiye, 2008). The cognitive component of attitudes represents beliefs, thoughts, and qualities we assign to an object. Affective component of the attitudes depends on the emotions or feelings that are related to an attitude object. The behavioral component of the attitudes represents past behaviors or experiences related to an attitude object (Maio \& Haddock, 2015). Thus, while cognitive schemes such as beliefs, views, perceptions or knowledge are included in the cognitive components, fear, anxiety or self-efficacy perception are included in the effective components. Thus, mathematical beliefs can be considered as a cognitive component, while fear or math, math anxiety or math self-efficacy perception can be considered as affective components. All past experiences are included in the behavioral components. In this context, beliefs of teachers/pre-service teachers on math teaching and learning, and their anxiety toward math teaching can be considered as a subcomponent of attitudes toward math teaching.

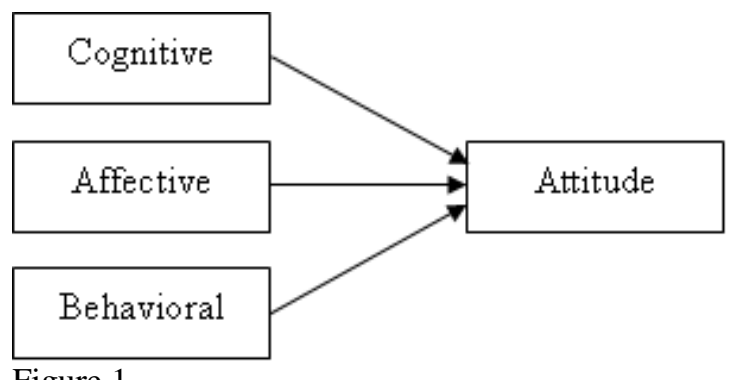

Figure 1

The Multicomponent Model of Attitude (Maio \& Haddock, 2015)

Math-related beliefs are described as decisions shaped by the individual's ideas and experiences on the nature of math, math teaching and math learning (Raymond, 1997), and teachers' and pre-service teachers' beliefs on the nature of math, math teaching and math learning filter their ideas acquired from their experiences and shape their teaching (Kayan, Haser, \& Işıksal-Bostan, 2013). Many studies claim that teachers' beliefs on math dominate in-class teaching and learning activities (Stipek, Givvin, Salmon, \& MacGyvers, 2001; Fang, 1996; Thompson, 1992, Pajares,1992; Kayan, Haser, \& Işıksal Bostan, 2013). Initially, there were three belief models on the nature of math, math teaching and math learning, which accept beliefs as a phenomenon generated as a result of experiences, and beliefs on math were studied in three developmental stages (Ernest, 1989; Thompson, 1991; Lindgren, 1996). The first one of these stages comprises beliefs in which the teacher is at the center, the student is passive, and math is regarded as a stationary system. The second stage comprises teacher-centered beliefs in which the students are active, and the importance of causes and relationships in math are considered important. The third stage comprises student-centered beliefs in which the 
teacher has a guiding position, and math is considered as a dynamic, ever-expanding system of correlations. However, when the studies conducted in later years are analyzed, teachers' beliefs are divided into two, which are traditional beliefs where the teacher puts $\mathrm{him} /$ herself at the center and constructivist beliefs where the student is at the center (Howard, Perry \& Lindsay, 1997; Oğuz, 2011; Şahin \& Y1lmaz, 2011; Kayan, Haser \& Iş1ksal-Bostan, 2013; Aypay, 2014). Howard, Perry, and Lindsay (1997) described teachers' beliefs on the nature of math and math teaching and learning as "traditional" and "constructivist", and stated that these beliefs have an influence on their math teaching. While Swan (2006) describes math teachers as the ones who practice traditionally as the transfer of mathematical rules and evidences, immediately followed by intense exercises to ensure fluency, constructivist math teachers are described as the ones who make students active and ensure that students reach mathematical rules and evidence on their own, and allow for the students to come up with solutions suitable for themselves while solving the problems on the course subject. Of these two beliefs, constructivist beliefs have a more positive influence on the teaching-oriented affective development of pre-service teachers than the traditional beliefs (Green \& Zimmerman, 2000; Hart, 2002; McCombs, 2001).

One of the anxiety types included in the cognitive components that affect attitudes is the math teaching anxiety. While teaching anxiety is defined as the anxiety related to the teaching process involving the preparation and practice of in-class activities (Gardner \& Leak, 1994), math teaching anxiety is defined as the tension and anxiety the teachers/pre-service teachers experience while teaching mathematical concepts, theorems, formula or problem solving (Peker, 2006). Teaching anxiety includes three different components, which are anxiety about being evaluated, anxiety about maintaining discipline, and anxiety about being able to teach effectively (Parsons, 1973). On the other hand, math teaching anxiety includes four different components, which are anxiety about content knowledge, anxiety about self-confidence, anxiety about the attitude toward math teaching and anxiety about pedagogical content knowledge (Peker, 2006). There are studies in the literature on the correlation between pre-service teachers' math teaching anxiety and their perception of self-efficacy (Ural, 2015), beliefs on self-efficacy (Peker, 2015; 2016a), beliefs regarding math (Ertekin, 2010), beliefs regarding epistemology (Ertekin, Dilmaç, Yazıcı, \& Peker, 2010), and correlation between pre-service primary school teachers' math teaching anxiety and their beliefs regarding math teaching and learning (Başpınar \& Peker, 2016). However, there have been studies on different practices that can have potential effects on math teaching anxiety, and traditional methods seem not to be effective (Peker, 2009a; 2009b).

Some studies from different disciplines have measured the correlation between the cognitive and affective components of attitudes (Ostrom, 1969). Affective responses affect the attitudes in a number of ways (Maio \& Haddock, 2015). Also, some other have investigated the correlation between beliefs regarding math, which belongs to cognitive and affective components, and math anxiety (Uusimaki \& Nason, 2004; Walsh, 2008; Haciömeroğlu, 2013), and the correlation between beliefs regarding math and math teaching anxiety (Ertekin, Dilmaç, Yazıcı \& Peker, 2010; Peker, 2016b; Başpınar \& Peker, 2016). However, there is a limited number of studies on the 
correlation between the components of pre-service teachers' beliefs on math teaching and learning and the components of math teaching anxiety (Peker, 2016b; Başpınar \& Peker, 2016). In their study on pre-service primary school teachers, Başpınar and Peker (2016) found no significant correlation between traditional beliefs, which is a component of beliefs on math teaching and learning, and anxiety about content knowledge, anxiety about self-confidence, anxiety about attitude toward math teaching and anxiety about pedagogical content knowledge, which are the components of math teaching anxiety. In the same study, they found a moderate level, negative and significant correlation between the constructivist beliefs, which is one of the components of beliefs regarding math teaching and learning, and anxiety about content knowledge, attitude toward math teaching and pedagogical content knowledge, which are the components of math teaching anxiety; and a low level, negative and significant correlation between the constructivist beliefs and anxiety about self-confidence. A similar study was performed on math teachers by Peker (2016b).

Due to a number of correlational studies on beliefs and teaching anxiety of pre-service math teachers, no study has investigated the direction of these variables through a structural equation model so far. In this study, the effect of the components of the beliefs on math teaching and learning on the components of math teaching anxiety was investigated for filling this gap in the literature. The outline generated for this study is given in Figure 2.

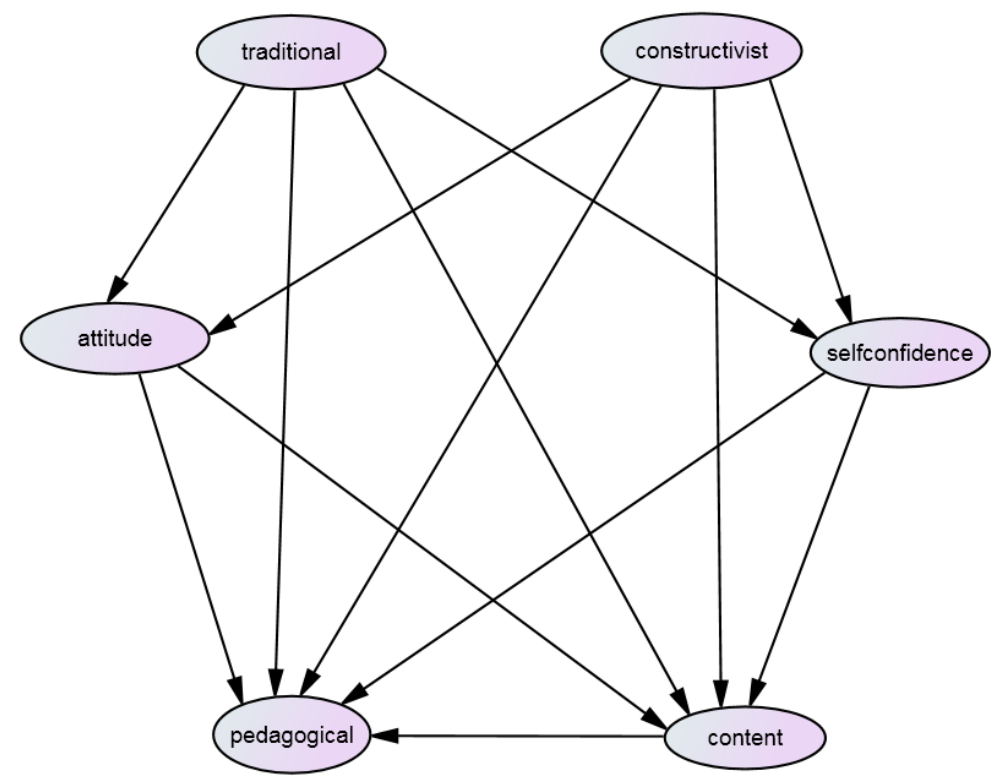

Figure 2

The first structural equation model that was tested

In this context, the following hypotheses were set within the scope of the research.

International Journal of Instruction, July $2018 \bullet$ Vol.11, No.3 
1. The traditional beliefs of pre-service high school math teachers about math have an effect on the anxiety about pedagogical content knowledge regarding math teaching.

2. The constructivist beliefs of pre-service high school math teachers about math have an effect on the anxiety about pedagogical content knowledge regarding math teaching.

\section{METHOD}

The study, which investigates the presence and the level of the effect of pre-service math teachers' beliefs (traditional, constructivist) on math teaching and learning on their math teaching anxiety (anxiety about content knowledge, self-confidence, attitude toward math teaching, pedagogical content knowledge), is performed using predictive correlational survey model. In predictive correlational studies, the correlations between two or more variables are investigated and one of the variables is predicted based on the other variable (Büyüköztürk, Çakmak, Karadeniz, \& Demirel, 2011, p. 277). In studies where predictive correlational model used, the independent variable affecting the other variable is treated as a predictor one, while the affected and tried to be predicted one is treated as a predicted variable (Creeswell, 2005). In this context, pre-service math teachers' beliefs (traditional, constructivist) are treated as apredictor, math teaching anxiety (anxiety about content knowledge, self-confidence, attitude toward math teaching, pedagogical content knowledge) are treated as a predicted variable.

\section{Participants}

The study group of the study comprises pre-service high school mathematics teachers who are registered to Pedagogical Formation Education Certificate Program in the Faculty of Education of a state university in Aegean region in Turkey. These participants attended pedagogical content classes such as special teaching methods, instructional technologies and material design in addition to certain pedagogical classes in the first term of pedagogical formation education. They also went to the state schools for teaching practice class while attending other education classes in the second term of pedagogical formation education. The study initially included a total of 248 pre-service high school math teachers, 154 of which were female and 94 of which were male.

The total number of items is 49 in the two scales. In the equation model studies, sample size should be 5-times more than the number of items, and a sample size less than 150 is not sufficient for a structural equation model analysis (Byrne, 2010; Kline, 2005; Şimşek, 2007; Anderson and Gerbing, 1988). In this context, the sample size proposed for the study is $245(49 \times 5)$. Therefore, the study group comprises 248 pre-service teachers for this study, and this meets the criteria that the participant number of the study group size is both the 5-times more than the number of items and more than 150 participants.

In multiple regression models, in order to see whether there are any extreme values that hamper meeting the normality assumptions, Mahalanobis Distance is measured (Çokluk, Şekercioğlu, \& Büyüköztürk, 2010). In this context, Mahalanobis Distance was measured in order to determine the extreme values that distort the assumption of normality. Of the 248 pre-service teachers participating in the survey, the responses of 
the 19 had extreme values and these pre-service teachers were excluded from the study. With the exclusion of 19 pre-service teachers with extreme values from the study, the study group of the study comprised 229 pre-service teachers, $145(63.3 \%)$ of which were female and $84(36.7 \%)$ of which were male.

\section{Instruments}

For data collection, two different scales were conducted on the pre-service mathematics teachers in the study group. The first one of the scales is the Mathematics Teaching Anxiety Scale (Peker, 2006). The objective of this scale is to determine the anxiety of pre-service mathematics teachers towards mathematics teaching. Mathematics Teaching Anxiety Scale is a 5-Likert type scale that comprises a total of 23 items with 4 subfactors. The sub-factors of the scale are anxiety about content knowledge that comprises 10 items, anxiety about self-confidence that comprises 6 items, anxiety about the attitude toward math teaching that comprises 4 items, and anxiety about pedagogical content knowledge that comprises 3 items. Şimşek (2007) suggests that factor structure should be revised when a scale is used in different study groups. Another pre-service high school math teachers were also included in the sampling group during the process of developing the original of the math teaching anxiety scale. Since the study group of is different, a confirmatory factor analysis was performed, and the factor structure of the scale was revised. At the end of the confirmatory factor analysis, it was observed that the scale retained its original structure of 23 items with four factors and has good fit $\left(\chi^{2} /\right.$ $\mathrm{SD}=1.598, \mathrm{RMSEA}=0.048, \mathrm{TLI}=0.91, \mathrm{IFI}=0.95, \mathrm{GFI}=0.90)$. In the present study, the Cronbach Alpha coefficient for the reliability of the overall scale was found as 0.93 , and the coefficients were 0.88 for the anxiety about content knowledge sub-factor, 0.86 for the anxiety about self-confidence sub-factor, 0.89 for the anxiety about attitude toward math teaching sub-factor, 0.85 for the anxiety about pedagogical content knowledge sub-factor.

The second scale is the Mathematics-Related Beliefs Scale developed by Kayan, Haser, and Işıksal-Bostan (2013). The objective of this scale is to explore the beliefs of preservice math teachers about mathematics teaching and learning. Mathematics-Related Beliefs Scale is a 5 Likert type scale which comprises 26 items and two sub-factors. The sub-factors of the scale are "Constructivist Beliefs" consisting of 20 items and "Traditional Beliefs" consisting of 6 items. The original form of beliefs about math was developed on pre-service math teachers. Due to the study group differences, a confirmatory factor analysis was also performed on this scale, and the results of this analysis revealed that the compatibility between the scale's original structure with two factors and the model is low. In order to increase the model compatibility, some modification indexes were analyzed. The items i1, i2, i5, i15, i20, i24, i25 and i26 were excluded from the scale because they belong to constructivist teacher beliefs factor that generates many errors and causes the greatest decrease in chi-square value when excluded from the scale. The errors between items i8-i9, i12-i13 and i21-i22 were set free. After the exclusion of items and combination of the errors, the scale generated good fit with its 11-item constructivist belief dimension and 6-item traditional belief dimension $\left(\chi^{2} / \mathrm{SD}=1.695, \quad \mathrm{RMSEA}=0.053, \quad \mathrm{TLI}=0.91, \quad \mathrm{IFI}=0.93, \mathrm{GFI}=0.92\right) . \quad$ The 
Cronbach Alpha coefficient was calculated as 0.83 for the reliability of the overall scale, and these values were 0.85 for the constructivist beliefs sub-factor and 0.77 for traditional beliefs sub-factor.

\section{Data Collection and Data Analysis}

In the process of collecting the data, mathematics teaching anxiety scale and mathematics-related beliefs scale were applied to the pre-service high school math teachers who were sampled and registered in the pedagogical formation education certificate program. Pre-service teachers participated in the research filled in the scales given to them voluntarily. As mentioned above, pre-service teachers took some courses about the content and pedagogical content knowledge. They also went to teaching practice class at high schools.

Structural equation models have become increasingly prevalent in social sciences in recent years, and they have been used for the evaluation of the data in studies (Çetin and F1kırkoca, 2010). For the compatibility of the model, the results were analyzed through "Chi-Square/ degrees of freedom $\left(\chi^{2} / \mathrm{SD}\right)$, Root Mean Square Error of Approximation (RMSEA), Incremental Fit Index (IFI), Tucker-Lewis Index (TLI), Comparative Fit Index (CFI)" fit indexes as the frequently used ones (Byrne, 2010; Schermelleh-Engel, Moosbrugger and Müller, 2003; Şimşek, 2007). To test the statistical significance of the mediation, Sobel z-test was performed (Sobel, 1982).

\section{FINDINGS}

In this study, we investigated the presence and the level of effect of pre-service mathematics teachers' beliefs (traditional, constructivist) on mathematics teaching and learning on mathematics teaching anxiety (anxiety about content knowledge, anxiety about self-confidence, anxiety about the attitude toward mathematics teaching, anxiety about pedagogical content knowledge). Firstly, we determined descriptive statistics and correlation values of the variables in this study. Table 1 shows these values.

Table 1

Correlation and descriptive statistics of the variables in the model

\begin{tabular}{lllllll}
\hline & Traditional & Constructivist & Attitude & $\begin{array}{l}\text { Self- } \\
\text { confidence }\end{array}$ & Content & Pedagogical \\
\hline Traditional & 1 & $.343^{* * *}$ & -.112 & $-.184^{* * *}$ & -.069 & $-.176^{* *}$ \\
\hline Constructivist & $.343^{* *}$ & 1 & $-.354^{* * *}$ & $-.326^{* * *}$ & $-.351^{* * *}$ & $-.477^{* * *}$ \\
\hline Attitude & -.112 & $-.354^{* * *}$ & 1 & $.656^{* * *}$ & $.498^{* * *}$ & $.526^{* *}$ \\
\hline $\begin{array}{l}\text { Self } \\
\text { confidence }\end{array}$ & $-.184^{* *}$ & $-.326^{* *}$ & $.656^{* *}$ & 1 & $.521^{* *}$ & $.468^{* *}$ \\
\hline Content & -.069 & $-.351^{* * *}$ & $.498^{* * *}$ & $.521^{* * *}$ & 1 & $.508^{* *}$ \\
\hline Pedagogical & $-.176^{* * *}$ & $-.477^{* * *}$ & $.526^{* *}$ & $.468^{* *}$ & $.508^{* *}$ & 1 \\
\hline Mean & 22.55 & 47.26 & 6.80 & 12.74 & 22.55 & 5.58 \\
\hline S.D & 3.51 & 5.11 & 2.35 & 3.63 & 6.05 & 1.97 \\
\hline $\mathrm{N}$ & 229 & 229 & 229 & 229 & 229 & 229 \\
\hline$* *$ Lev & 229 & & & & \\
\hline
\end{tabular}

** Level of significance is 0.01 .

Büyüköztürk (2006) stated that the correlation between two variables is low if between $0-0.29$, moderate if between $0.30-0.69$, and high if between $0.70-1.00$. In this context, as 
can be seen in Table 1, the correlation is low between the traditional beliefs of preservice teachers and the sub-factors of math teaching anxiety, while the correlation is moderate between the constructivist beliefs of pre-service teachers and the sub-factors of math teaching anxiety.

The hypothesis model of the study presented in Figure 1 was tested but the traditional beliefs of the pre-service teachers did not affect the sub-factors of the teaching anxiety. In this context, the first hypothesis which was set as "The traditional beliefs of preservice high school math teachers about math have an effect on the anxiety about pedagogical content knowledge regarding math teaching" was rejected. Therefore, this factor was excluded from the model.

The second hypothesis of the research which was set as "The constructivist beliefs of pre-service high school math teachers about math have an effect on the anxiety about pedagogical content knowledge regarding math teaching" was tested. The anxiety about self-confidence regarding math teaching did not affect the anxiety about pedagogical content knowledge, and the anxiety about attitudes toward math teaching did not affect the anxiety about math content knowledge, and thus the paths defined between these variables were excluded from the model. Following these steps, the final model was constructed, and the fit index values regarding the model were given in Table 2.

Table 2

Fit indexes criteria values and fit index values regarding the model

\begin{tabular}{llll}
\hline Fit indexes & Good Fit & Acceptable Fit & Values from Model 1 \\
\hline$\chi^{2} / \mathrm{sd}$ & $0 \leq \chi^{2} / \mathrm{df} \leq 2$ & $2<\chi^{2} / \mathrm{sd} \leq 5$ & 2.29 \\
\hline RMSEA & $0 \leq \mathrm{RMSEA} \leq .05$ & $.05<\mathrm{RMSEA} \leq .08$ & .04 \\
\hline IFI & $0.95 \leq \mathrm{IFI}<1.00$ & $0.90 \leq \mathrm{IFI}<0.95$ & .90 \\
\hline TLI & $0.95 \leq \mathrm{TLI}<1.00$ & $0.90 \leq \mathrm{TLI}<0.95$ & .92 \\
\hline CFI & $0.95 \leq \mathrm{CFI}<1.00$ & $0.90 \leq \mathrm{CFI}<0.95$ & .92 \\
\hline GFI & $0.95 \leq \mathrm{GFI}<1.00$ & $0.90 \leq \mathrm{GFI}<0.95$ & .91 \\
\hline
\end{tabular}

In Table 2, it can be seen that fit values regarding the model are acceptable $\left(\chi^{2} / \mathrm{SD}=2.29\right.$; RMSEA=0.04; IFI=0.90; TLI=0.92; CFI=0.92; GFI=.91) (Byrne, 2010; SchermellehEngel, Moosbrugger and Müller, 2003; Şimşek, 2007). Total effects, direct and indirect effects regarding the dependent and independent variables in the model were shown in Table 3. 
Table 3

Effects of the dependent and independent variables in the final model

\begin{tabular}{lllllll}
\hline $\begin{array}{l}\text { Independent } \\
\text { variable }\end{array}$ & $\begin{array}{l}\text { Dependent } \\
\text { variable }\end{array}$ & $\begin{array}{l}\text { Total } \\
\text { effect }\end{array}$ & $\begin{array}{l}\text { Direct } \\
\text { effect }\end{array}$ & $\begin{array}{l}\text { Indirect } \\
\text { effect }\end{array}$ & $\begin{array}{l}\text { Standard } \\
\text { error }\end{array}$ & C.R. \\
\hline Constructivist & Self-confidence & -.453 & -.453 & - & .143 & -4.635 \\
\hline Constructivist & Content & -.503 & -.220 & -.283 & .096 & -3.126 \\
\hline Constructivist & Attitude & -.493 & -.493 & - & .117 & -5.020 \\
\hline Constructivist & Pedagogical & -.674 & -335 & -.339 & .101 & -3.684 \\
\hline Self-confidence & Content & .625 & .625 & - & .082 & 6.956 \\
\hline Self-confidence & Pedagogical & .304 & - & .304 & - & - \\
\hline Attitude & Pedagogical & .346 & .346 & - & .067 & 4.859 \\
\hline Content & Pedagogical & .335 & .335 & - & .060 & 4.515 \\
\hline
\end{tabular}

$* *$ Level of significance is 0.01 .

In Table 3, it can be seen that the constructivist beliefs of pre-service teachers negatively and directly affect the anxiety about self-confidence regarding math teaching $(\beta=-.453$, C.R.=-4.635, $p<.01)$, anxiety about the attitude toward math teaching $(\beta=-.493$, C.R. $=-$ $5,020, \mathrm{p}<.01)$. It was also found that constructivist beliefs of pre-service teachers affect anxiety about content knowledge regarding math teaching $(\beta=-503)$, and this effect is direct $(\beta=-220, C . R .=3.126, p<.01)$, and negative via the anxiety about self-confidence regarding math teaching $(\beta=-.283)$. Sobel $\mathrm{z}$-test was conducted to examine whether the mediating effect of the anxiety related to self-confidence had an effect on the effect of the constructivist views of pre-service math teachers on content knowledge, and the results of this test were found to be significant (Sobel $Z=-2.923 ; p<.01$ ). The constructivist beliefs of pre-service teachers also affect anxiety about pedagogical content knowledge regarding math teaching $(\beta=-674)$, and this effect is both direct $(\beta=-$ 335 , C.R. $=3.684, \mathrm{p}<.01)$ and negative through the anxiety about attitudes toward math teaching $(\beta=-.339)$. In order to investigate whether the mediator effect of the anxiety about attitudes toward math teaching for the effect of pre-service teachers' constructivist beliefs on anxiety about math content knowledge is significant, Sobel Z test was performed, and the result was significant (Sobel $\mathrm{Z}=-3.780 ; \mathrm{p}<.01$ ). It was found that anxiety about self-confidence regarding math teaching directly affects the anxiety about math content knowledge $(\beta=.625, C . R .=6.956, p<.01)$, and affect the anxiety about pedagogical content knowledge regarding math teaching via the anxiety about math content knowledge $(\beta=.304)$. In order to determine whether the mediator effect of the anxiety about math content knowledge for the effect of anxiety about self-esteem regarding math teaching on anxiety about content education knowledge is significant, Sobel $\mathrm{Z}$ test was performed, and it was found that the result was significant (Sobel $\mathrm{Z}=$ $4.448 ; \mathrm{p}<.01)$. In the study, it was found that anxiety about attitudes toward math teaching directly affects the anxiety about pedagogical content knowledge $(\beta=.346$, C.R. $=4.859, \mathrm{p}<.01)$ and anxiety about math content knowledge directly affect anxiety about pedagogical content knowledge $(\beta=.335, C . R .=4.515, p<.01)$. Variance rates in the final model show that constructivist beliefs represent $21 \%$ of the variance in anxiety about self-confidence regarding math teaching and $24 \%$ of the variance in anxiety about attitudes toward math teaching. It was found that the pre-service teachers' constructivist 
beliefs and anxiety about self-confidence regarding math teaching represent $56 \%$ of the variance in anxiety about math content knowledge; and the pre-service teachers' constructivist beliefs, anxiety about self-confidence regarding math teaching, anxiety about attitudes toward math teaching, and anxiety about math content knowledge represent $63 \%$ of the variance in anxiety about pedagogical content knowledge. The final model was shown in Figure 2.

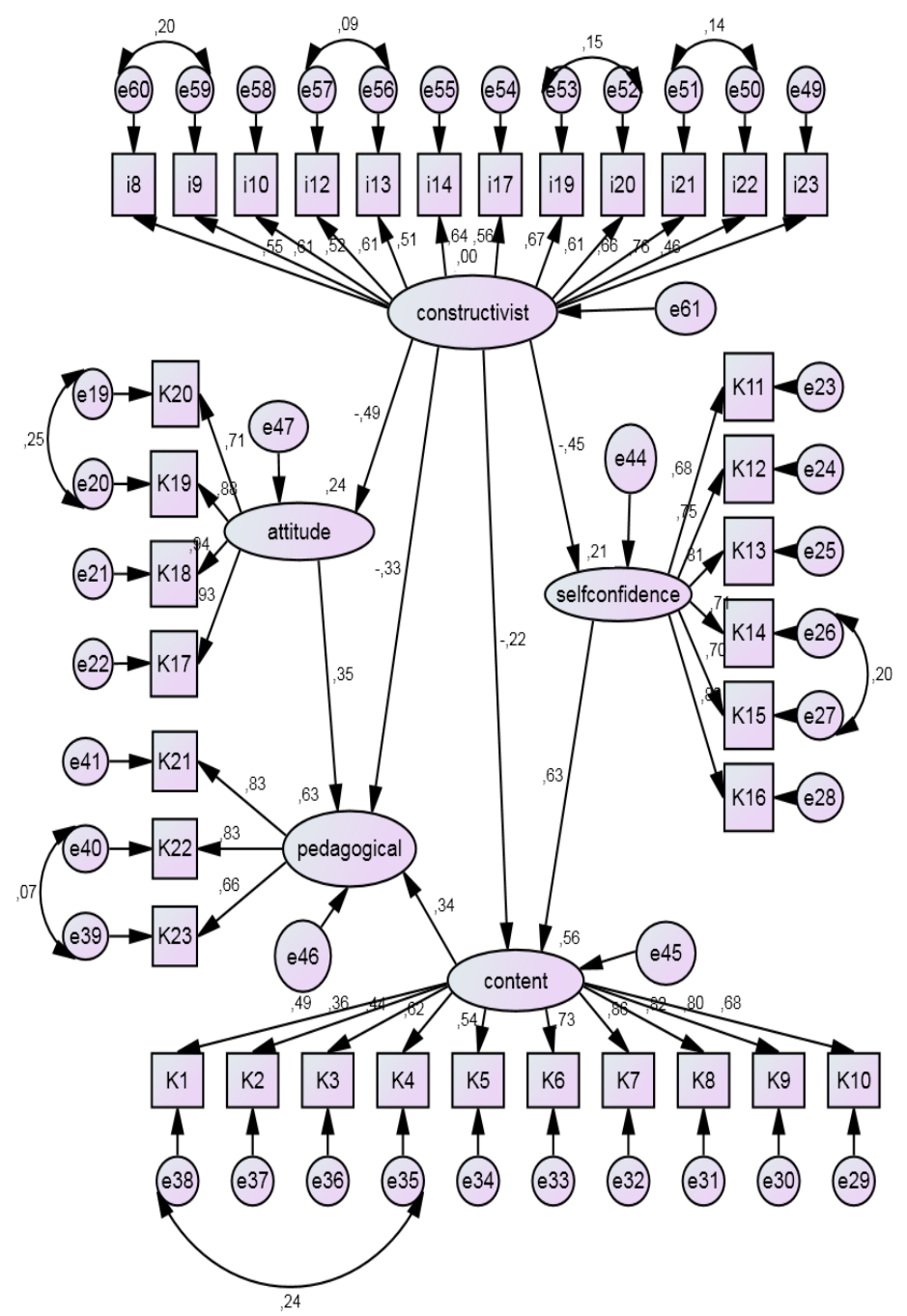

Figure 3

The main structural equation model 
In this context, it was seen that the constructivist beliefs of pre-service high school math teachers about math have an effect on the anxiety about pedagogical content knowledge regarding math teaching and the second hypothesis of the research was accepted.

\section{DISCUSSION AND CONCLUSION}

In the literature, there is a limited number of studies on the correlation between the components of pre-service teachers' beliefs on math teaching and learning and the components of math teaching anxiety (Peker, 2016b; Başpınar and Peker, 2016). However, whether the components of the beliefs on math teaching and learning have an effect on the components of the anxiety about math teaching or vice versa has not been clearly explained. In this study, the presence and the level of effect of pre-service mathematics teachers' beliefs (traditional, constructivist) on mathematics teaching and learning on mathematics teaching anxiety (anxiety about content knowledge, anxiety about self-confidence, anxiety about the attitude toward mathematics teaching, anxiety about pedagogical content knowledge) were investigated. The results of the present study have yielded five conclusions.

The first conclusion is that traditional beliefs do not affect anxiety about content knowledge, self-confidence, attitudes and pedagogical content knowledge. These results are similar to the results of the study by Başpınar and Peker (2016). In their study on pre-service primary school teachers, Başpınar and Peker (2016) found no significant correlation between traditional beliefs and anxiety about self-confidence, attitude, and pedagogical content knowledge. However, the results of the present study are partially similar to the results of the study by Peker (2016b). Peker (2016b) has found no significant correlation between traditional beliefs and teaching anxiety about content knowledge and attitude, whereas there was a low level, negative, a significant correlation between traditional beliefs and teaching anxiety about self-confidence and pedagogical content knowledge. Moreover, Peker (2009a/2009b) has revealed whether the traditional teaching environments have an effect on the math teaching anxiety of preservice teachers; and the results of the study are similar to the results of the present study.

The second conclusion is that constructivist beliefs moderately and negatively affect the teaching anxiety about attitudes, and they represent $24 \%$ of the change in teaching anxiety about attitudes. In the studies by Başpınar and Peker (2016) and Peker (2016b), a negative, moderately significant correlation was detected between constructivist beliefs and anxiety about the attitude toward math teaching, and the results of these studies support the results of the present study.

The third conclusion of the study is that constructivist beliefs negatively moderately affect the teaching anxiety about self-confidence and represents $21 \%$ of the variance in teaching anxiety about self-confidence. These results are similar to the results of the study by Peker (2016b). Peker found a negative, moderately significant correlation between constructivist beliefs and anxiety about self-confidence. However, the results of the present study are different from the results of the study by Başpınar and Peker (2016). In their study on pre-service primary school teachers, Başpınar and Peker (2016) 
found a negative correlation with the low level of significance between constructivist beliefs and anxiety about self-confidence.

The fourth conclusion of the study showed that constructivist beliefs affect anxiety about content knowledge directly and also via the anxiety about self-confidence, the direct effect was negatively low, and although the mediation effect of the anxiety about selfconfidence was low, total effect level was found to be intermediate. It was found that anxiety about self-confidence directly moderately affects anxiety about content knowledge. The direct and indirect effects of constructivist beliefs, direct effects of attitudes, indirect effects of self-confidence, direct effects of content knowledge represent $63 \%$ of the variance in anxiety about pedagogical content knowledge. In the studies by Başpınar and Peker (2016) and Peker (2016b), a negative, moderately significant correlation was detected between constructivist beliefs and anxiety about the attitude toward math teaching, and the results of this study support the results of the present study.

The fifth conclusion of the study demonstrated that constructivist beliefs significantly affect anxiety about pedagogical content knowledge both directly and via anxiety about attitudes, the direct effect is negative and moderate, and although the mediator effects of the anxiety about attitudes are moderate, the overall effect is close to high level. It was found that anxiety about attitudes directly moderately affects anxiety about pedagogical content knowledge. It was also observed that anxiety about self-confidence is significantly moderately affected via anxiety about pedagogical content knowledge. The anxiety about content knowledge directly moderately affects pedagogical content knowledge. The direct and indirect effects of constructivist beliefs, direct effects of attitudes, indirect effects of self-confidence, direct effects of content knowledge represent $63 \%$ of the variance in anxiety about pedagogical content knowledge. In their study, Yazıc1, Peker, Ertekin and Dilmaç (2011) found that pre-service teachers' constructivist values are the predictors of math teaching anxiety, and in other related studies, Başpınar and Peker (2016) and Peker (2016b) found a negative, moderately significant correlation between constructivist beliefs and anxiety about pedagogical content knowledge, and the results of these studies partially corroborate with the results of the present study.

To conclude, the traditional beliefs, one of the belief types toward math teaching and learning, have no effect on the anxiety of pre-service math teachers toward math teaching. However, the constructivist beliefs seem to have an effect on the anxiety of pre-service math teachers toward math teaching. In addition to the previous correlational studies, this study explored the direction and level of the relationship between the beliefs and teaching anxiety. Thus, raising pre-service teachers as the beholders of constructivist beliefs is of importance in the education process of math teachers. The absence of another study that investigates whether the components of beliefs on math teaching and learning have an effect on the components of anxiety about math teaching or vice versa among pre-service teachers reveals the importance of the results of the present study. 


\section{Limitation and further study}

The results of this study are limited to the data of the pre-service math teachers in the study group. However, pre-service primary school teachers, pre-service elementary math teachers, pre-service high school math teachers are the teachers who will teach math in the future. Thus, in the next studies, a similar study can be conducted using a larger sample group that includes pre-service primary school teachers, pre-service elementary math teachers and pre-service high school math teachers. The results of the future potential studies can be compared with the results of the present study.

Considering these limitations, similar studies can be performed with pre-service teachers in different countries, and the results can be compared with the results of the present study.

\section{REFERENCES}

Akinsola, M.K. \& Olowojaiye, F.B. (2008). Teacher instructional methods and student attitudes towards mathematics. International Electronic Journal of Mathematics Education, 3(1), 60-73.

Anderson, J.C. \& Gerbing D.W. (1988). Structural equation modeling in practice: A review and recommended two - step approach. Psychological Bulletin, 103, 411-423.

Aypay, A. (2014). Epistemolojik inançlar ölçeğinin Türkiye uyarlaması ve öğretmen adaylarının epistemolojik inançlarının incelenmesi. Eskişehir Osmangazi Üniversitesi Sosyal Bilimler Dergisi, 12(1), 1-15.

Başpınar, K. \& Peker, M. (2016). The relationship between pre-service primary school teachers' mathematics teaching anxiety and their beliefs about teaching and learning mathematics. Kuramsal Eğitimbilim Dergisi [Journal of Theoretical Educational Science ], 9(1), 1-14.

Büyüköztürk, Ş. (2006). Verianalizi el kitabı. Ankara: Pegem A Yayıncılık.

Büyüköztürk, Ş., Kılıç Çakmak E., Akgün, Ö. E., Karadeniz, Ş. \& Demirel, F. (2011). Bilimsel araştırma yöntemleri (10. bs.). Ankara: Pegem A Yayıncılık.

Byrne, B. M. (2010). Structural equation modeling with AMOS, (2nd ed.). New York: Routledge.

Creswell, J. W. (2005). Educational research: Planning, conducting, and evaluating quantitative and qualitative research. Upper Saddle River, NJ: Merrill/Prentice Hall.

Çetin, F. \& Fıkırkoca, A. (2010). Can the extra role positive behaviors be predicted by personal and attitudinal factors?. Ankara University Journal of Faculty of Political Science, 65(4), 41-66.

Çokluk, Ö., Şekercioğlu, G. \& Büyüköztürk, Ş. (2010). Sosyal bilimler için çok değişkenli istatistik. Ankara: Pegem Akademi. 
Ernest, P. (1989). The impact of beliefs on the teaching of mathematics. Paper prepared for ICME VI, Budapest, Hungary.

Ertekin, E. (2010). Correlations between the mathematics teaching anxieties of preservice primary education mathematics teachers and their beliefs about mathematics. Educational Research and Reviews, 5(8), 446-454.

Ertekin, E., Dilmaç, B., Yazıcı, E. \& Peker, M. (2010). The relationship between epistemological beliefs and teaching anxiety in mathematics. Educational Research and Reviews, 5(10), 631-636.

Fang, Z. 1996. A review of research on teacher beliefs and practices. Educational Research, 38(1), 47-65.

Gardner L., \& Leak G. (1994). Characteristics and correlates of teaching anxiety among college psychology teachers. Teaching of Psychology, 21(1), 28-32.

Greene, M. W., \& Zimmerman, S. O. (2000). The effects of fifth dimension on preservice teachers beliefs. Paper presented at the Society for Information Technology ve Teacher Education International Conference (San Diego, California).

Haciömeroğlu, G. (2013). Mathematics anxiety and mathema $\neg$ tics beliefs: What is the relationship in elementary pre-service teachers? IUMPST, 5, 1-9. Retrieved from http://www.k-12prep. math.ttu.edu/journal/attributes/ haciomeroglu02/article.pdf

Hart, L. (2004). Beliefs and perspectives of first year alternative preparation elementary teachers in urban classrooms. School Science and Mathematics, 104(2), 79-88.

Howard, P., Perry, B., \& Lindsay, M. (1997). Secondary mathematics teachers' beliefs about the learning and teaching of mathematics. In People in mathematics education. Proceedings of the 20th Annual Conference of the Mathematics Education Research Group of Australasia (pp. 231-238).

Kayan, R., Haser, Ç. \& Işıksal Bostan, M. (2013). Matematik öğretmen adaylarının matematiğin doğası, öğretimi ve öğrenimi hakkındaki inanışları. Eğitim ve Bilim, 38(167), 179-195.

Kline R.B. (2005). Principles and practice of structural equation modeling. New York: Guilford Pressp. 154-186.

Lindgren, S. (1996). Thompson's levels and views about mathematics. An analysis of Finnish preservice teachers' beliefs. Zentralblatt für Didaktik der Mathematik, 28, 113 117.

Maio, G.R., \& Haddock, G. (2015). The psychology of attitudes and attitude change (2nd Edition). London: SAGE Publications Ltd.

McCombs, B. L. (2001). What do we know about learners and learning? Learnercentered framework: Bringing the educational system into balance. Educational Horizons, 79(4), 182- 193. 
Oğuz, A. (2011, Eylül). Öğretmen adaylarının demokratik değgerleri ile öğretme ve ögrenme anlayışlarının incelenmesi. XX. Ulusal Eğitim Bilimleri Kurultayı, Mehmet Akif Ersoy Üniversitesi Eğitim Fakültesi, Burdur.

Ostrom, T. M. (1969). The relationship between the affective, behavioral, and cognitive components of attitude. Journal of Experimental Social Psychology, 5(1), 12-30.

Pajares, M. F. (1992). Teachers' beliefs and educational research: Cleaning up a messy construct. Review of Educational Research, 62(3), 307-332.

Parsons, J. S. (1973). Assessment of Anxiety About Teaching Using the Teaching Anxiety Scale: Manual and Research Report. ERIC Document Number: ED 079330

Peker, M. (2006). Matematik öğretmeye yönelik kaygı ölçeğinin geliştirilmesi. Ĕ̆itim Bilimleri ve Uygulama Dergisi, 9, 73-92.

Peker, M. (2009a). The use of expanded microteaching for reducing pre-service teachers' teaching anxiety about mathematics. Scientific Research and Essays, 4(9), 872-880.

Peker, M. (2009b). The effects of an instruction using problem solving strategies in Mathematics on the teaching anxiety level of the pre-service primary school teachers. The New Educational Review, 19(3-4), 95-114.

Peker, M. (2015, October). The relationship between mathematics teaching anxiety and self-efficacy beliefs toward mathematics teaching. International Conference on Social Sciences and Education Research, Antalya-Turkey.

Peker, M. (2016a). Mathematics teaching anxiety and self-efficacy beliefs toward mathematics teaching: A path analysis. Educational Research and Review, 11(3), 97104.

Peker, M. (2016b, October). Pre-Service mathematics teachers' mathematics teaching anxiety and their beliefs about teaching and learning mathematics. International Human And Nature Sciences: Problems and Solution Seeking Congress, Sarajevo, Federation of Bosnia and Herzegovina.

Raymond, A. M. (1997). Inconsistency between a beginning elementary school teacher's mathematics beliefs and teaching practice. Journal for Research in Mathematics Education, 28, 550-577.

Schermelleh-Engel, K., Moosbrugger, H. \& Muller, H. (2003). Evaluating the fit of structural equation models: Tests of significance and descriptive goodness-of-fit measures. Methods of Psychological Research Online, 8(2), 23-74.

Stipek, D. J., Givvin, K. B., Salmon, J. M., \& MacGyvers, V. L. (2001). Teacher's beliefs and practices related to mathematics instruction. Teaching and Teacher Education, 17, 213-226. 
Şahin, S., \& Y1lmaz, H. (2011). A confirmatory factor analysis of the teaching and learning conceptions questionnaire (TLCQ). Journal of Instructional Psychology, 38(3), 194-200.

Şimşek, Ö. F. (2007), Yapısal Eşitlik Modellemesine Giriş (Temel İlkeler ve LISREL Uygulamaları). Ankara: Ekinoks.

Sobel, M. E. (1982). Asymptotic intervals for indirect effects in structural equations models. In S. Leinhart (Ed.), Sociological methodology 1982 (pp.290-312). San Francisco: Jossey-Bass.

Swan, M. (2006). Collaborative learning in mathematics: A challenge to our beliefs and practices. London: National Institute for Advanced and Continuing Education (NIACE); National Research and Development Centre for Adult Literacy and Numeracy (NRDC).

Thompson, A. G. (1991). The development of teachers' conceptions of mathematics teaching. In: Proceedings of the Thirteenth Annual Meeting of the North American Chapter of the International Group for the Psychology of Mathematics Education, 2, 814.

Thompson, A. G. (1992). Teachers' beliefs and conceptions: A synthesis of the research: In D. A. Grouws (Ed.), Handbook of research on mathematics teaching and learning (pp. 127-146). New York: Macmillan.

Ural, A. (2015). Matematik öz-yeterlik algısının matematik öğretmeye yönelik kaygıya etkisi. Kuramsal Ĕgitimbilim Dergisi, 8(2), 173-184.

Uusimaki, L. \& Nason, R. (2004, July). Causes underlying pre-service teachers' negative beliefs and anxieties about mathematics. In Proceedings of the 28th Conference of the International Group for the Psychology of Mathematics Education (Vol. 4, pp. 369-376).

Walsh, K. A. (2008). The relationship among mathematics anxiety, beliefs about mathematics, mathematics self-efficacy, and mathematics performance in associate degree nursing students. Nursing Education Perspectives, 29(4), 226-229.

Yazıcı, E., Peker, M., Ertekin, E., \& Dilmaç, B. (2011). Is there a relationship between pre-service teachers' mathematical values and their teaching anxieties in mathematics? Electronic Journal of Research In Educational Psychology, 9(1), 263-282. 